\title{
Sudden Onset Permanent Deafness as an Early Complication of Bacterial Meningitis
}

\author{
Ankita Goel · Suvasini Sharma • Satinder Aneja
}

Received: 31 December 2012 / Accepted: 23 May 2013 /Published online: 20 June 2013

(C) Dr. K C Chaudhuri Foundation 2013

To the Editor: Bacterial meningitis is a frequent cause of acquired deafness in children. Clinically significant hearing impairment has been documented in $10.5 \%$ of affected children and is bilateral or profound in $5.1 \%$ [1]. Though deafness is a common sequel of meningitis, sudden onset permanent deafness occurring as an early complication of bacterial meningitis is unusual.

A 9-y-old previously healthy girl was admitted to our hospital with complaints of fever, vomiting and irritability for last $3 \mathrm{~d}$. She also complained of headache and neck stiffness and photophobia. There was no history of seizures, altered sensorium, or rash. On examination, she was alert but irritable. She was able to answer our questions. She had neck rigidity along with a positive Kernig's sign without focal neurological deficits. She was started on ceftriaxone, along with intravenous fluids. She did not receive dexamethasone. Lumbar puncture revealed turbid cerebrospinal fluid (CSF), with cytology of 1,600 cells/mm [3], all polymorphs. The CSF protein was elevated $(160 \mathrm{mg} / \mathrm{dL})$ and sugar reduced (CSF/Blood sugar ratio 0.4). The CSF culture was sterile.

The following day, she was better; the fever and irritability had reduced. On the third day of hospital stay, she complained of not being able to hear even loud sounds. A brainstem evoked response audiometry showed absent responses in both ears at 135 decibel stimulation. A contrast enhanced MRI of the brain revealed no abnormalities. There were no other neurologic sequelae. The pure tone audiometry at discharge revealed bilateral profound sensorineural

\footnotetext{
A. Goel $\cdot$ S. Sharma $(\bowtie) \cdot S$. Aneja

Department of Pediatrics, Lady Hardinge Medical College and associated Kalawati Saran Children's Hospital, New Delhi 110001, India

e-mail: sharma.suvasini@gmail.com
}

hearing loss. On follow-up after $3 \mathrm{mo}$, there was no improvement in the hearing loss. She has been referred for cochlear implant surgery.

Hearing loss develops early in the course of meningitis. Richardson et al., reported the results of ota-accoustic emissions performed as soon as possible after diagnosis, and repeated at 6-12, 12-24, and 36-48 $\mathrm{h}$, and at discharge, in 124 children with bacterial meningitis [2]. The authors demonstrated that 3 children $(2.5 \%)$ had permanent deafness. The cochlea was identified as the site of the lesion.

The role of corticosteroids in reducing severe hearing loss among the survivors of meningitis is controversial [3]. Two recent meta-analyses showed no difference in the auditory sequelae on combining steroids with the standard treatment of bacterial meningitis $[4,5]$.

Use of early testing by brainstem reflex audiometry or ota-accoustic emissions can help in early recognition of deafness in children with bacterial meningitis and ensure follow-up with appropriate and timely management.

\section{References}

1. Baraff LJ, Lee SI, Schriger DL. Outcomes of bacterial meningitis in children: A meta-analysis. Pediatr Infect Dis J. 1993;12:389-94.

2. Richardson MP, Reid A, Tarlow MJ, Rudd PT. Hearing loss in bacterial meningitis. Arch Dis Child. 1997;76:134-8.

3. Brouwer MC, McIntyre P, de Gans J, Prasad K, van de Beek D. Corticosteroids for acute bacterial meningitis. Cochrane Database Syst Rev. 2010;9:CD004405.

4. Bernardo WM, Aires FT, Sá FP. Effectiveness of the association of dexamethasone with antibiotic therapy in pediatric patients with bacterial meningitis. Rev Assoc Med Bras. 2012;58:319-22.

5. van de Beek D, Farrar JJ, de Gans J, Mai NT, Molyneux EM, Peltola $\mathrm{H}$, et al. Adjunctive dexamethasone in bacterial meningitis: A metaanalysis of individual patient data. Lancet Neurol. 2010;9:254-63. 